\title{
Inquiring, Inventing, and Integrating: Applying Human-Centered Design to the Challenges of Future Governments
}

\section{Sabine J unginger}

Lucerne University of Applied Sciences and Arts-Art and Design, sabine.junginger@hslu.ch

Abstract: The challenges of future governments involve opportunities for the conception, planning, and delivery of new government services. Applying the principles and methods of humancentered design offers an alternative path for how we go about designing them. Inquiring into existing design practices allows for the discovery of new forms of design thinking and the application of new design methods and processes. A focus on human experience and human interaction promotes innovation and inventions, newly integrates public organizations, and directly contributes to the creation of public value by benefitting the individual, government, and society.

Keywords: human-centered design, digitalization, future government, public services, innovation

Acknowledgement: I am grateful for the opportunity to present my initial thoughts on this topic as a keynote at the 2018 EGov-CeDem-ePart conference at the Danube University Krems, Austria. This paper builds on comments and feedback, and reflects on the growth of my own thinking.

\section{Design and All Things (E-) Government}

"Everyone who devises courses of action to turn an existing situation into a preferred one, is a designer." 1

We are increasingly concerned with design in government, because of the fact that our design practices and our design methods are nowhere near as consequential in policy-making and in policy implementation as they could be. Services (and other products) that result from these design

\footnotetext{
${ }^{1}$ Quote from Herbert A. Simon (1996). The Sciences of the Artificial. Cambridge, NJ: MIT Press, 3rd Edition.
} 
activities tend to shape the lives of millions of people. It is an area where human-centered design principles and design methods can make a major contribution to achieve policy goals that involve public sector innovation and actual social changes. The efforts towards electronic government, electronic participation, electronic democray, and open government are currently in the process of giving shape to products and services that will result in specific interactions and experiences of individual people with their governments. This is one of the reasons we are talking about humancentered design today. Much of this design approach centers on user-experiences with a specific focus on methods of user-centered design. My focus here, however, will be on the application of human-centered design to the challenges of future government. My aim is to show how humancentered design promotes the inquiry into, the invention, and the integration of future forms of governance.

Most governments were invented a long time ago. The principles around which they have taken form and, which in turn, have shaped laws to maintain order have their roots in the experiences, values, and social norms of their time, as well as in the technological capabilities and the understanding of business and management of that era. ${ }^{2}$ Government, therefore, presents itself as a product of human thought and human action. Government also represents a special kind of organization. Like all organizations, it involves people creating structures, people making use of resources, and (at least in a democracy) doing so by following commonly established and agreed upon processes. Ideally, the execution of these tasks is geared towards fulfilling the mandate of enhancing human living.

All this identifies government as a product of design. If nobody designed government, then government, or any other organization for this matter, would not exist. It, therefore, poses no difficulty to approach government and the problem of governance as a matter, yes, even as a problem of design. For some this may offer a new perspective; however, within the discipline of design, organizations have long been understood to hold the key for human experience and human interaction. Industrial designer, George Nelson, for example, pointed to organizations as a problem of design in 1957, because of the way organizations affect human living:

"One of the most significant facts of our time is the predominance of the organization. Quite possibly, it is the most significant. It will take time to realize its full effect on the thinking and behavior of individuals. In this conditioning process, few escape its influence. ${ }^{3}$

Herbert A. Simon's observation that everyone is a designer who devises courses of action to turn an existing situation into a preferred one, is relevant for those currently engaged in improving

${ }^{2}$ These relationships are well explained by Richard McKeon, whose work on 'Communication, Truth and Society' demonstrates the role of communication as central to a functioning society. Also relevant, is the work of John Dewey who has written on The Public and its Problems (1927) as well as on Art as Experience (1934). I offer a full introduction to Design in Government in Junginger, S. (2017). Transforming Public Services by Design: Re-orienting Policies, Organizations and Services around People and discuss organizational 'design legacies' in the paper 'Design Legacies and Service Design,' the Design Journal 2015.

${ }^{3}$ Nelson, G. (1979). Problems of Design, Watson-Guptill Publications; 4th edition 
administrative processes in government. Simon, who also shed light on administrative behavior, reminds us that researchers and practitioners that pursue electronic government, electronic participation, e-democracy, and open government engage in design activities and produce design outcomes. After all, their very aim is to arrive at a preferred state of governance-one that involves new structures, new processes, and new services that digital and artificial technologies can afford to citizens and governments.

Within ministries, public organizations, and government agencies, we find a range of design practices - yet few employ design methods to inquire into their organizational system, to invent future organizational forms, and with that, to integrate future services and operational demands with the mandates they strive to fulfill. If we take the dual challenges of an aging public sector workforce and a push for digitalization, we realize quickly that those two challenges will severely impact the internal workings of public organizations. But this is not only applicable to an overall aging population with more active and more vocal citizens (and non-citizens) and thinner public budgets. This calls for a re-evaluation of what constitutes public value, how public value may be delivered, and to what public. In this context, designing digital services has to involve future scenarios and organizational development. Anyone restricting the design of digital services to make printed paper forms available online as PDF or who focuses exclusively on translating existing analog services into digital offerings made available on a platform will effectively avoid the hard question of what must be achieved to secure a functioning public sector organization in the future. Essentially, this means that before we start to design, we need to ask ourselves 'how do we go about designing?'

\section{How Do We Go About Designing?}

Since everyone involved in electronic government, electronic participation, e-democracy and open government already is in the processes of designing, the lingering question is how designing takes place in these contexts and what designing encompasses. Understanding what kind of design thinking is present in an organization, what kind of design principle guides and steers attempts at innovation, and allows for adjustments as well as for the introduction of new design thinking (around new design principles and the use of new or different design methods and processes) is of paramount importance. Absence of such an inquiry into design practices and a general willingness to experiment with new design approaches, for example, leaves little chance for any of the 17 Sustainable Development Goals 2030+ to be achieved. After all, whatever we have tried so far has not produced the kind of outcome we want. As design goes, when the outcome of a design effort fails to produce the outcome desired, we revisit if our design principles, research methods, and making processes were appropriate and properly applied. With the SDGS and public management in mind, we might very well ask the question proposed by Richard Buchanan (2015):

"What principle has been neglected in earlier design theories of management and how does new design thinking come forward with a different perspective on management, innovation and entrepreneurship?" 
Strangely enough, the one principle we find being neglected way too often is the one of innovating around people-of being human-centered. This is strange in that the business of government first and foremost is 'to enhance human living' by way of social justice, social coherence, human dignity, and human rights. We would expect to find design principles based on human experiences and human interactions among policy-makers and public managers. We would also expect anyone working with policy-makers and public managers on matters of public services (and other forms of access to government) to be literate in different design practices and familiar with humancentered design. The answer to the question of 'how do we go about designing' begins, therefore, with an analysis of 'how might we design.'

\subsection{Designing, Changing, Organizing, and Managing}

To understand the role of design, and specifically human-centered design, one has to look at the relationships that exist among designing, changing, organizing, and managing. ${ }^{4}$ When we design, that is when we conceive of, plan, develop, realize, and implement a new product or service. This is done with the goal to improve an existing situation into a preferred one, and in order to reach this goal we have to make some sort of changes. We simply cannot design without making any change whatsoever. Without change, things stagnate and stay just the way they are presently. Figure 1 depicts designing, changing, organizing, and managing as interdependent activities.

If we think of designing, for a moment, as bringing something into being or as making something that did not exist before, we can see that designing cannot happen without changing something. The activity of designing will depend on who we design for and on the purpose of our final design. Importantly, the diagram does not answer these two questions: who designs what and for what purpose. Likewise, the diagram does not show: what changes, how, or for what reason. A change achieved through design may be as simple and superficial as a change in colors or materials. Alternatively, we may change how things are being produced or how people think about a product. We may seek to change how people actually use a product or we may change the kind of experiences people may have when engaging with a product or service. Change by design can even include changes in value. Whenever we change something, we engage in some sort of organizing or reorganizing. We might reorganize matters like physical materials or structural elements. We may also reorganize hierarchies, locations, places, or our thoughts. The intent of the diagram is to reflect on how we actually go about designing and how we may go about designing.

The level of innovation we may accomplish through our design efforts depends on our ability to manage the overall design process. Through management, we set the stage for how product development can become a tool of inquiry into the organization; through our managing activities, we can ensure that we do not lose focus of what got us started to design in the first place (the purpose of our doing). The exact purpose in the public sector is clear: to enable public organizations

\footnotetext{
${ }^{4}$ For a fuller explanation of this relationship see Junginger, S. (2017). Transforming Public Service by Designreorienting Policies, Organizations and Services around People, Routledge.
} 
and government agencies to fulfil their purpose of enhancing human living and to do so by developing innovative products that serve people.

Figure 1: The Four Core Organizational Activities: Designing, Changing, Organizing, and Managing5

\section{Inquiring, Inventing, Integrating}

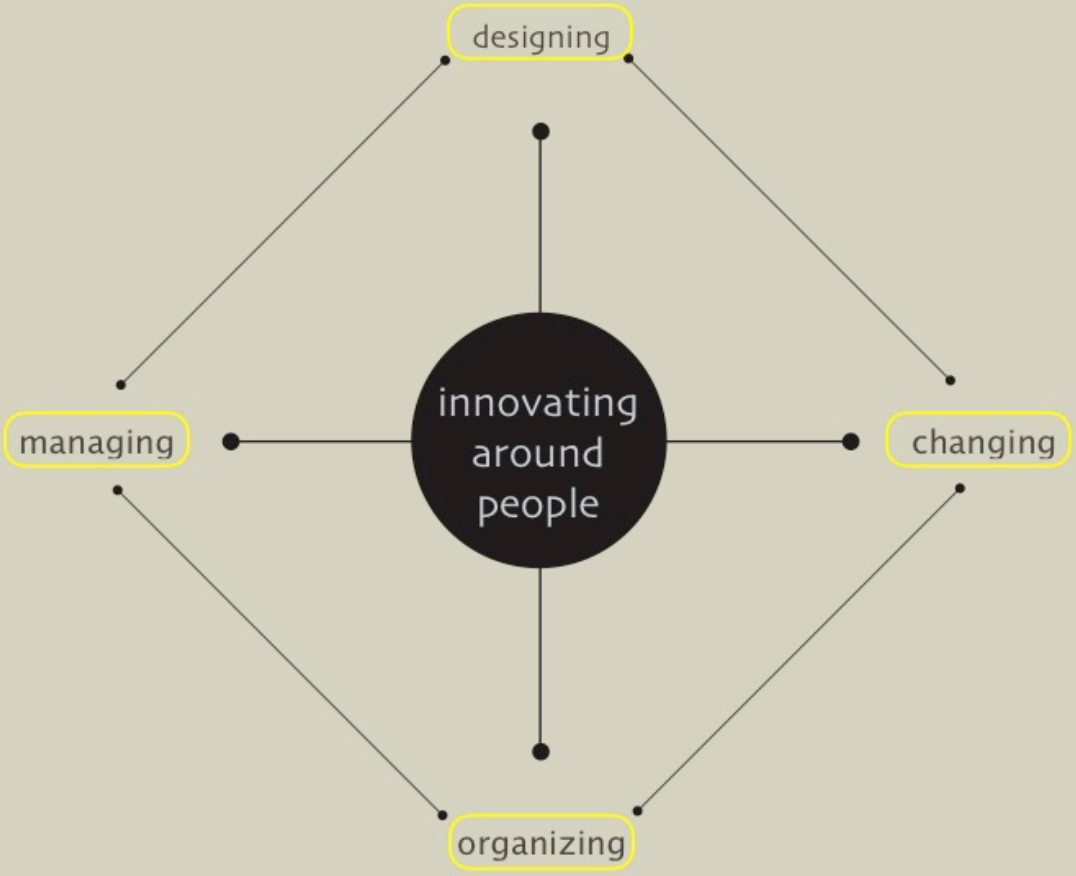

\subsection{Emergent and Deterministic Design Management}

There are many ways to manage people, organizations, and projects. When it comes to managing design and design efforts, we can distinguish between two key management approaches. The first approach best serves an organization that knows what kind of product it has determined as being ideal as an outcome or what kind of service they want. This approach to design management can be described as deterministic management because the outcome is determined from the onset. This kind of design management makes sense in the context of 'tame problems' (Rittel and Webber, 1973) and in the context of organizational 'exploitation' (March 1991). A tame problem can be complex in its overall characteristic, like the design of a suburb or an airport. What makes such a

5 See Junginger, S. (2017). 
problem tame and the outcome determined is the fact that we already know that in the end we will produce a suburb or an airport.

An emergent design management approach allows for discovery and invention for the final product. We simply do not know what the final product will be, as part of our design activities involve a new understanding of a given situation and the reframing of a problem (Schön und Rein, 1993 \& 1994; Dorst). In this design management approach, exploration (March, 1991) is key and the nature of the problem remains ill-defined in the beginning or 'wicked' (Rittel and Webber, 1973).

These two design management approaches are not always clearly articulated. In fact, we can witness situations where the design efforts undertaken by designers of electronic government, electronic participation, electronic democracy, and open government are not clear in terms of their ambitions. Both design management approaches can work well, but to develop new innovative solutions requires the skill of managing emergent design processes. At this stage, it is not clear how prepared designers in these areas are. Likewise, it is not clear if the field generally has a preference for one design management approach over another. What we do see mostly is deterministic design management, and with that, we see innovation being limited.

Deterministic design management seems to serve the current need of the public sector to catch up with digital technologies. However, we already see the shortcomings of such an approach. One such example is the legal agreement among municipalities, states, and federal governments in Germany to allow for the digital application for specific services following the introduction of the Online Zugangsgesetz (OZG). This law took several years of negotiations among these different government entities. By the time the agreement finally got signed, Austria's government had already developed a way to avoid the need for citizens to submit applications by anticipating their needs. Imagine what would have happened if the German actors would not have been obsessed with taking the status-quo as a starting point, but instead if they would have started with a vision of how they want citizens to engage with their government. Much time and money could have been saved and the shift into the digital age sped up. This example illustrates in a nutshell the importance of envisioning future forms of government services, and points to the limitations of extending one's current understanding of public services and public organizations into the digital future. To put simply, how we go about designing matters.

\section{Design Management for Emergence Applied to New Technologies}

The ways in which design management for emergence can support organizational learning, restructuring, and re-orientation around people are manifold. However, all require the involvement of stakeholders from different areas of the organization and different levels of staff. If we return to the two key issues German, Austrian, and Swiss public administrations will have to cope with over the next decade-a severe decimation of its workforce due to a retirement wave that is reinforced by troubles of recruiting young people into the public sector, and the demands imposed by digitalization and shifts to electronic processes and services that have yet to be developed - we can illustrate how design management focused on emergence and guided by human-centered design principles may generate new possibilities. 
What would happen, for example, if the Logistics and Informatics department of a public organization would collaborate with the personnel department and one or two organizational areas affected most by the pending retirements. What if these stakeholders would engage with people they mean to serve (citizens, other institutions), and conduct a design inquiry to find out about future needs and future wants? What if such a work group would develop a common futureoriented vision for this organization, based on how they could envision new services, new roles for staff, and new organizational structures suitable to support such a new organizational form?

To some, this may all sound like a bit of imaginary blue-sky stuff disconnected from organizational reality. It is always easier to manage for deterministic outcomes. However, to get ready for the future - to understand what public value constitutes in light of new technological possibilities and new relationships between citizens and government - this is the path few can avoid. Design activities and design efforts geared to achieve a functional digital government will make use of design thinking and design methods one way or another. It remains our responsibility to explore future public services and future forms of public organizations. How we go about designing really matters.

\section{Critique on Human-Centered Design: Non-Anthropocene Design}

Since I delivered this keynote, a sort of backlash has formed among design theorists against the idea of centering design efforts around human beings. I feel it is necessary to address this development. For some scholars, "human-centered" has come to stand for a kind of design practice that is (and perhaps never has been) sustainable. They rightly point out that with many of our technological, cultural, social, and economic developments we humans have wreaked havoc on our planet, our environment, and in particular on nature itself. For these scholars, the concept of 'human-centered design' embraces the depletion of limited resources through human action. The term 'non-anthropocene design' has been coined to emphasize a comprehensive systemic view in which humans are not at the top of the hierarchy of the living. ${ }^{6}$ Designing here, begins with a concern for the living system overall and makes an effort to reduce the impact humans have on this ecological system.

${ }^{6}$ Recent research in design on this topic includes Jönsson, L. (2014). Design events: On explorations of a nonanthropocentric framework in design. The Royal Danish Academy of Fine Arts, School of Design; Avila, M. (2012). Devices. On Hospitality, Hostility and Design. HDK - School of Design and Crafts Faculty of Fine, Applied and Performing Arts, University of Gothenburg, Sweden; Roudavski, S. 2019, 'Notes on Morethan-Human Architecture', in Undesign: Critical Practices at the Intersection of Art and Design, eds. G. Coombs, A. McNamara \& G. Sade, Routledge, Abingdon, GB, pp. 24-37. Malm, A. (2018). The Progress of This Storm: On Society and Nature in a Warming World. London: Verso.; Sandelin, E. (2018). Designer and Goldcrest. Malmö: Sorgenfri Press; Weisberg, Z. (2014). 'The Trouble with Posthumanism: Bacteria are People Too, ' in Sorenson, J., ed. Critical Animal Studies. Thinking the Unthinkable. Toronto: Canadian Scholars' Press, 93-116; Williams, A. (2004). 'Disciplining animals: Sentience, Production, and Critique'. The International journal of sociology and social policy, 24(9), pp. 45-57. 
This critique of human-centered design, in my view, reflects a limited understanding of a principled, human-centered design approach. Sometimes, this is more obvious, for example, when human-centered design is used synonymously with 'user-centered design.' 7 The latter, indeed, focuses on the experiences and interactions of an individual human being with a particular object, service, or other product. User-centered design can be described as a one-to-one interaction. Human-centered design, in contrast, contextualizes and (to a certain extent) qualifies this one-to-one interaction by bringing it into the fold of the one and the many; in the public sector, of course, the individual experience and interaction has to be considered and addressed. Yet, the overall design of a public service requires a careful balance of all kinds of issues, in particular those that communicate and foster social values, contribute to social cohesion, and those of social justice. In government design, we are concerned with both: with the design of public services that are useful, usable, and meaningful to those people that should have access to them (user-centered), and that communicate and foster trust and confidence in the government by strengthening social justice, social coherence, human rights, and human dignity so as to enable participation in society (humancentered).

Furthermore, the value of human-centered design rests precisely in the recognition that no matter what people conceive of, invent, plan, deliver, and finally bring to life (wherever and in whatever material or immaterial form), ultimately, it will always affect humans in one way or another. The task and responsibility of enhancing human living requires us to take into account natural resources, technological possibilities, as well as flora and fauna alike. As living beings, the damages that result from our inventions (their intended and unintended consequences), will always come back to haunt us and harm us - just like it will harm all other life on our planet and universe. Thus, many of our past and present design practices do not pass as human-centered. Our trust in technologies is shrinking due to technological liabilities we only now realize: be that plastics, $\mathrm{CO} 2$ production, or nuclear energy. In all three cases, the principle has been one of advancing technologies first and then to figure out how we can-through technologies-mediate the side-effects for people. ${ }^{8}$ All this leads me to argue that human-centered design and non-anthropocene design essentially pursue a similar aim, though one (human-centered design) begins and ends with people, while the other (non-anthropocene design) begins and ends with non-human entity.

\footnotetext{
${ }^{7}$ For a more detailed discussion see Junginger, S. Transforming Public Service by Design: Re-orienting Policies, Organizations and Services around People, Routledge 2017.

8 The fact that scientists have now traced plastics in human stool points illustrates the absence of humancentered design principles in many of our designs. See: Robbie Gonzales (2018). 'Your Poop is probably full of plastic,' Wired online, https://www.wired.com/story/your-poop-is-probably-full-of-plastic/ [accessed December 2018].
} 


\section{How We Go About Designing Future Governments}

When we understand that everyone designs and everything is design, the question is no longer 'what is design' but 'how do we go about designing'. ${ }^{9}$ Enhancing design capabilities across government (be that in the area of policy-making or policy implementation) in regards to public services or in regards to taking advantage of the multitude of technologies, will be the key to a sustainable, pro-active, and anticipatory public sector. Ultimately, the challenge for all participants of this conference remains to produce something of value and relevance for people-something that enhances human living not just because it builds trust and confidence in government.

Too often, we fail to inquire into human experiences and human interaction when designing public policies and public services. Just as often and due to this lack of inquiry, we miss opportunities to envision an organization's future possibilities, thereby missing chances to realign organizational processes, structures, and resources around the purpose and mandate the organization strives to fulfill. A human-centered design perspective in the public sector encourages us to reflect critically on our current design principles and practices, our design processes, and methods: Do they serve the organization well? Do they produce the kinds of outcomes to fulfill an organization's mandate, and do they do so by considering how organizational processes and services contribute to enhance human experience and human interactions of citizens, staff, and others? Lastly, are there better ways of going about designing future government services?

\section{References}

Avila, M. (2012). Devices. On Hospitality, Hostility and Design. HDK - School of Design and Crafts Faculty of Fine, Applied and Performing Arts, University of Gothenburg, Sweden.

Buchanan, R. (2015). 'Worlds in the Making: Design, Management, and the Reform of Organizational Culture,' she ji The Journal of Design, Economics, and Innovation Issue No.1, Autumn 2015: 5-21.

Dewey, J. (1927). The Public and its Problems. Ohio University Press.

Dewey, J. (1934). Art as Experience, New York, Minton, Balch and Company, New York.

Dorts. K. (2015). Frame Innovation. MIT Press.

Gonzales, R. (2018). 'Your Poop is probably full of plastic,' Wired online, https://www.wired.com/story/your-poop-is-probably-full-of-plastic/ [accessed December 2018].

Jönsson, L. (2014). Design events: On explorations of a non-anthropocentric framework in design. The Royal Danish Academy of Fine Arts, School of Design.

Junginger, S. (2015). 'Design Legacies and Services Design', The Design Journal, ?(?), ??-??.

${ }^{9}$ Manzini, E. (2016). When everyone designs, ... 
Junginger, S. (2017). Transforming Public Services by Design - Re-orienting Policies, Organizations and Services around People. Oxford: Routledge.

Malm, A. (2018). The Progress of This Storm: On Society and Nature in a Warming World. London: Verso.

March, J. G. (1991). 'Exploration and Exploitation in Organizational Learning,' Organization Science, Vol. 2, No. 1, Special Issue: Organizational Learning: Papers in Honor of (and by) James G. March (1991), pp. 71-87.

McKeon, R. (190). ‘Communication, Truth and Society', Ethics, Vol. 67, No. 2 (Jan., 1957), pp. 89-99.

Nelson, G. (1979). Problems of Design, Watson-Guptill Publications; 4th edition

Rein, M. and Schön, D. (1993). 'Reframing Policy Discourse', in Fischer, F. and J. Forrester (eds.), The Argumentative Turn in Policy Analysis and Planning, Duke University Press, 1993: 145-166.

Rein, M. and Schön, D. (1994). 'Reframing: Controversy and Design' in Policy Practice, New York: Basic Books.

Rittel, H. \& Webber, M. (1973). 'Dilemmas of General Theory of Planning', Policy Sciences, 4: 155-169.

Roudavski, S. 2019, 'Notes on More-than-Human Architecture', in Undesign: Critical Practices at the Intersection of Art and Design, eds. G. Coombs, A. McNamara \& G. Sade, Routledge, Abingdon, GB, pp. 24-37.

Sandelin, E. (2018). Designer and Goldcrest. Malmö: Sorgenfri Press.

Simon, H.A. (1996). The Sciences of the Artificial. Cambridge, NJ: MIT Press, $3^{\text {rd }}$ Edition.

Weisberg, Z. (2014). 'The Trouble with Posthumanism: Bacteria are People, Too', in Sorenson, J., ed. Critical Animal Studies. Thinking the Unthinkable. Toronto: Canadian Scholars' Press, 93-116.

Williams, A. (2004). 'Disciplining animals: Sentience, Production, and Critique'. The International journal of sociology and social policy, 24(9), pp. 45-57.

\section{About the Author}

Sabine J unginger

Sabine J unginger is the head of the Competence Center Design and Management at the Lucerne University of Applied Sciences and Arts - Art and Design in Switzerland. After an initial career in journalism with stints in Public Relations and detours via Market Research and Corporate Design, she graduated with an MA Design in Communication Planning and Information Design from Carnegie Mellon University in Pittsburgh. She was one of the first two recipients in 2006 who received the PhD in Design from Carnegie Mellon. She is fluent in English, German, and Swabian, and also gets by in Spanish and French. 